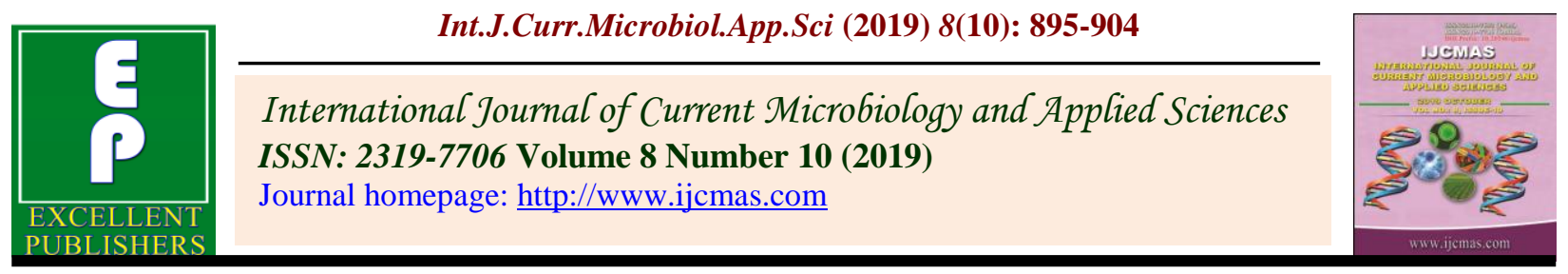

Original Research Article

https://doi.org/10.20546/ijcmas.2019.810.104

\title{
Estimation of Crop Water Requirement (CWR) of Major Vegetable Crops of Selected Agro-climatic Zones of Madhya Pradesh, India
}

\author{
Upma Gautam $^{1^{*}}$, A. K. Nema ${ }^{1}$ and R. K. Jaiswal ${ }^{2}$ \\ ${ }^{1}$ Department of Farm Engineering, I.A.S. Banaras Hindu University, Varanasi, 221005, India \\ ${ }^{2}$ National Institute of Hydrology, Bhopal, 462016, India \\ *Corresponding author
}

\begin{tabular}{|c|}
\hline Keywords \\
\hline $\begin{array}{l}\text { Crop water } \\
\text { requirement, } \\
\text { Vegetable crops } \\
\text { agro-climatic zone, } \\
\text { Evapotranspiration }\end{array}$ \\
\hline Article Info \\
\hline $\begin{array}{l}\text { Accepted: } \\
\text { 10 September } 2019 \\
\text { Available Online: } \\
10 \text { October } 2019\end{array}$ \\
\hline
\end{tabular}

A B S T R A C T
Crop water Requirement (CWR) is the key to design a suitable irrigation system for a particular crop. In this paper CWR of major vegetable crops for six agro-climatic zones of Madhya Pradesh is estimated on the basis of Reference Evapotranspiration. The study is performed for major vegetable crops namely tomato, onion, pea, brinjal, potato and okra. The crop water requirement found to vary with stages of the crop growth and the reference evapotranspiration. For most of the crops, water requirement is found maximum during development and mid season stage and found minimum during initial and maturity stages of the crops. The mean annual sum of CWR of vegetable crops in all districts was found highest for Brinjal, in winter season it is maximum in Barwani (32.87 litre) during peak period and minimum in Alirajpur (5.59 litre) during lean period whereas in monsoon season maximum in Neemuch (23.68 litre) during peak period and minimum in Jhabua (5.43 litre) during lean period and lowest for pea, in winter season it is maximum in Ratlam (6.22 litre) during peak period

\section{Introduction}

The term crop water requirement is defined as "amount of water required to the crop from its planting date to harvesting date". It also refers to the amount of water required to compensate the evapo-transpiration loss from cropped field. It depends on crop type, stage of growth and evaporation demand. The rapidly depleting water resources and agroenvironmental health threaten the sustenance of existing levels of agricultural production, and call for efficient use of water over space and time (Kumari et al., 2013). Hence estimation of CWR of various crops is necessary which will help in planning an accurate irrigation system to save best possible amount of available water. Accurate 
quantification of crop water requirements of any crop is essentially required for irrigation scheduling and water management (yadav et al., 2017).

It is "the depth of water needed to meet the water loss through evapotranspiration of a disease-free crop, growing in large fields under non-restricting soil conditions including soil water and fertility and achieving full production potential under the given growing environment. It is a function of crop characteristics, management, and environmental demands. Crop water requirement can be calculated from reference evapotranspiration using crop coefficient $\left(\mathrm{K}_{\mathrm{c}}\right)$.

The reference evapotranspiration $\left(\mathrm{ET}_{0}\right)$ can be explained as the rate at which readily available soil water is evaporated from specified vegetated surfaces (Jensen et al., 1990). ET is one of the most important variable in the hydrological cycle after rainfall which affects the spatial water requirement of the crops (Mohan and Arumugam, 1996). The FAO experts accepted the FAO Penman-Monteith method as a standard method for definition and computation of reference evapotranspiration (ETo) and crop water requirement. The FAO Penman-Monteith method provides consistent ETo values in all regions and climates (Allen et al., 1998).

The estimation of the water requirement of crops is one of the basic needs for crop planning of any irrigation project. A new technique for evaluation of Crop Water Requirement is introduced to standardize the fortnightly crop water requirement by introducing the concept of development of iso lines for crop water requirement for the Nagpur region. These iso lines will give directly crop water requirement at any location in region as well as it is useful for well irrigation (Hajare et al., 2008). After that climate change impact was studied on crop water requirement. Impacts of elevated temperatures of 1 to $4^{\circ} \mathrm{C}$ on crop water requirements of major crops of arid Rajasthan was studied by using PET and crop coefficient approach. (Rao and Poonia 2011). A study was made on Climate Change Impact on Crop Water Requirement in Ganga River Basin, West Bengal, India. In this study, potato was taken as the reference crop for its growing period and its high response to irrigation (Chatterjee et al., 2012). Some models are also used to directly estimate the reference evapotranspiration and water requirement using weather, soil and crop parametres as input. Crop water requirements of crops in Appapuram Channel Command under Krishna Western Delta is computed with CROPWAT using the meteorological parameters (Raju et al., 2016). A probability analysis of rainfall and crop water requirement is also conducted using CROPWAT model for crop planning in a canal command of upper Bhima Basin of Maharashtra (Sachan et al., 2016).

\section{Materials and Methods}

\section{Study area}

The study was carried out for six major vegetable crops prevailing in 30 districts of six agro-climatic zones of Madhya Pradesh. The state has three predominant seasons: winter (November to February), summer (March to May), and the monsoon season (June to September). The area consists of 6 agroclimatic zones namely Chhattisgarh plains, Gird region, Jhabua hills, Malwa plateau, Nimar plains and Northern hill region of Chhattisgarh which covers 30 districts namely Balaghat, Gwalior, Bhind, Morena, Sheopur, Shivpuri, Guna, Ahoknagar, Jhabua, Alirajpur, Mandsaur, Neemuch, Ratlam, Ujjain,Dewas, Indore, Shajapur, Rajgarh, Dhar, Agar Malwa, Khandwa, Burhanpur, Khargone, Barwani, Shahdol, Mandla, Dindori, Anuppur, Singrauli and Umaria. 


\section{Data collection}

Crop data were obtained from the NBSS \& LUP (National Bureau of Soil Survey and Land Use Planning, 2010) in the form of area covered under different crops. From this data three vegetable crops were chosen in a district on the basis of maximum covered area. Information of time of sowing and harvesting, length of crop development stages and crop coefficient $\left(\mathrm{K}_{\mathrm{c}}\right)$ values for crops were collected from the report published by FAO, 1998 (Table 1).

Water requirement is the quantity of water, regardless of its source, required by a crop or diversified pattern of crops in a given period of time for its normal growth under field conditions at a place (Michael., 1998). There are various parameters which are required for computation of crop water requirement namely reference evapotranspiration, crop coefficient, percent wetted area, and uniformity coefficient.

Reference evapotranspiration can be estimated from the aquacrop model using necessary weather parameters and percent wetted area can be obtained from Table 2 .

Water requirement can be estimated by following suggested formulas:

Water requirement for closely spaced row crops

$\mathrm{WR}=\frac{\text { sl } \times \mathrm{Sd} \times \mathrm{ETO} \times \mathrm{Kc} \times \mathrm{Wp}}{\mathrm{Fu}}$

Where,

$\mathrm{WR}=$ Crop water requirement, lit/day

$\mathrm{ET}_{0}=$ Reference evapotranspiration, $\mathrm{mm} /$ day

$\mathrm{Kc}=$ Crop coefficient

$\mathrm{Sl}=$ Lateral spacing along the sub main, (m)
$\mathrm{Sd}=$ Dripper spacing along the lateral, $(\mathrm{m})$

$\mathrm{Wp}=$ Percentage wetted area, decimal

$\mathrm{Eu}=$ Emission uniformity of drip irrigation system, decimal

The $\mathrm{K}_{\mathrm{cini}}$ and $\mathrm{K}_{\text {cmid }}$ values given in Table 3 were used as such for estimation of water requirement of initial and mid season stage but there are no pre set $k_{c}$ values for crop development and late season stage. For calculation of CWR at development stage $\mathrm{k}_{\mathrm{c}}$ value between $\mathrm{k}_{\mathrm{cini}}$ and $\mathrm{k}_{\mathrm{cmid}}$ was used and for late season between $\mathrm{k}_{\mathrm{cmid}}$ and $\mathrm{k}_{\text {cend }}$.

\section{Results and Discussion}

The crop water requirement for vegetable crops like tomato, potato, okra, pea, brinjal and onion during different season estimated and analysed are discussed below graphically. The crop water requirement found to vary with stages of the crop and the reference evapotranspiration. For most of the crops, water requirement is found maximum during development and mid season stage and found minimum during initial and maturity stages of the crops.

Among all vegetable crops under consideration the CWR of tomato in winter season is maximum in Ratlam (19.24 litre) during peak period and minimum in Shahdol (4.64 litre) during lean period whereas in summer season maximum in Mandsaur (29.88 litre) during peak period and minimum in Indore (5.17 litre) during lean period.

The CWR of potato in winter season is maximum in Dhar (7.33 litre) during peak period and minimum in Anuppur (4.64 litre) during lean period whereas in summer season maximum in Morena (8.14 litre) during peak period and minimum in Anuppur (2.58 litre) during lean period. 
The CWR of onion in winter season is maximum in Ratlam (9.94 litre) during peak period and minimum in Anuppur (0.97 litre) during lean period whereas in summer season maximum in Morena (13.14 litre) during peak period and minimum in Anuppur (2.12 litre) during lean period.
The CWR of Brinjal in winter season is maximum in Barwani (32.87 litre) during peak period and minimum in Alirajpur (5.59 litre) during lean period whereas in monsoon season maximum in Neemuch (23.68 litre) during peak period and minimum in Jhabua (5.43 litre) during lean period (Fig. 1-10).

Table.1 Selected major vegetable crops of study area

\begin{tabular}{|c|c|c|c|c|}
\hline Agroclimatic & \multirow[t]{2}{*}{ District } & \multicolumn{3}{|c|}{ Vegetable crops } \\
\hline Zones & & $1 \mathrm{st}$ & $2 \mathrm{nd}$ & $3 r d$ \\
\hline Chhattisgarh plains & Balaghat & Tomato & Brinjal & Onion \\
\hline \multirow[t]{7}{*}{ Gird region } & Gwalior & Pea & Potato & Tomato \\
\hline & Morena & Potato & Tomato & Onion \\
\hline & Bhind & Potato & Tomato & Onion \\
\hline & Shivpuri & Tomato & Onion & Potato \\
\hline & Sheopur & Potato & Tomato & Onion \\
\hline & Guna & Tomato & Potato & Onion \\
\hline & Ashoknagar & Potato & Tomato & - \\
\hline \multirow[t]{2}{*}{ Jhabua hills } & Jhabua & Tomato & Onion & Brinjal \\
\hline & Alirajpur & Tomato & Onion & Brinjal \\
\hline \multirow[t]{10}{*}{ Malwa plateau } & Mandsaur & Pea & Tomato & Okra \\
\hline & Neemuch & Okra & Tomato & Brinjal \\
\hline & Ratlam & Tomato & Onion & Pea \\
\hline & Ujjain & Onion & Potato & - \\
\hline & Dewas & Potato & Onion & - \\
\hline & Indore & Tomato & Onion & Potato \\
\hline & Shajapur & Onion & Potato & Okra \\
\hline & Rajgarh & Onion & Potato & Tomato \\
\hline & Dhar & Potato & Tomato & Onion \\
\hline & Agar malwa & Onion & Potato & Pea \\
\hline \multirow[t]{5}{*}{ Nimar plains } & Khandwa & Onion & Potato & Brinjal \\
\hline & burhanpur & Tomato & Potato & Onion \\
\hline & Khargone & Onion & Tomato & Potato \\
\hline & Barwani & Onion & Okra & Brinjal \\
\hline & Shahdol & Potato & Tomato & Okra \\
\hline Northern hill & Mandla & Pea & Tomato & Potato \\
\hline region of & Dindori & Pea & Potato & Tomato \\
\hline \multirow{3}{*}{ Chhattisgarh } & Anuppur & Potato & Onion & Okra \\
\hline & Singrauli & Potato & Onion & Tomato \\
\hline & Umaria & Potato & Tomato & - \\
\hline
\end{tabular}


Table.2 Percent wetted area of vegetable crops

\begin{tabular}{|c|c|}
\hline Crop & \% Wetted Area \\
\hline Potato & 75 \\
\hline Onion & 70 \\
\hline Tomato & 65 \\
\hline Okra & 70 \\
\hline Brinjal & 75 \\
\hline Cabba ge & 65 \\
\hline Cauliflower & 65 \\
\hline Pea & 70 \\
\hline Chilli & 75 \\
\hline
\end{tabular}

Table.3 Crop coefficient $\left(\mathrm{K}_{\mathrm{c}}\right)$ values of selected vegetable crops (source: FAO - 56 Allen et al., 1998)

\begin{tabular}{|c|c|c|c|}
\hline Crops & $\begin{array}{c}\text { Initial stage } \\
\left(\mathbf{K}_{\text {cini }}\right)\end{array}$ & $\begin{array}{c}\text { Mid-stage } \\
\left(\mathbf{K}_{\mathbf{c m i d}}\right)\end{array}$ & $\begin{array}{c}\text { Late stage } \\
\left(\mathbf{K}_{\text {cend }}\right)\end{array}$ \\
\hline Vegetables & & & \\
Potato & 0.50 & 1.15 & 0.75 \\
Onion & 0.70 & 1.05 & 0.75 \\
Tomato & 0.60 & 1.15 & 0.70 \\
Brinjal & 0.60 & 1.05 & 0.90 \\
Cabbage & 0.70 & 1.05 & 0.95 \\
Cauliflower & 0.70 & 1.05 & 0.95 \\
Pea & 0.50 & 1.05 & 0.30 \\
Chilli & 0.30 & 1.18 & 0.53 \\
\hline
\end{tabular}

Fig.1 Stage wise variation in CWR of tomato in winter season at various districts of Madhya Pradesh

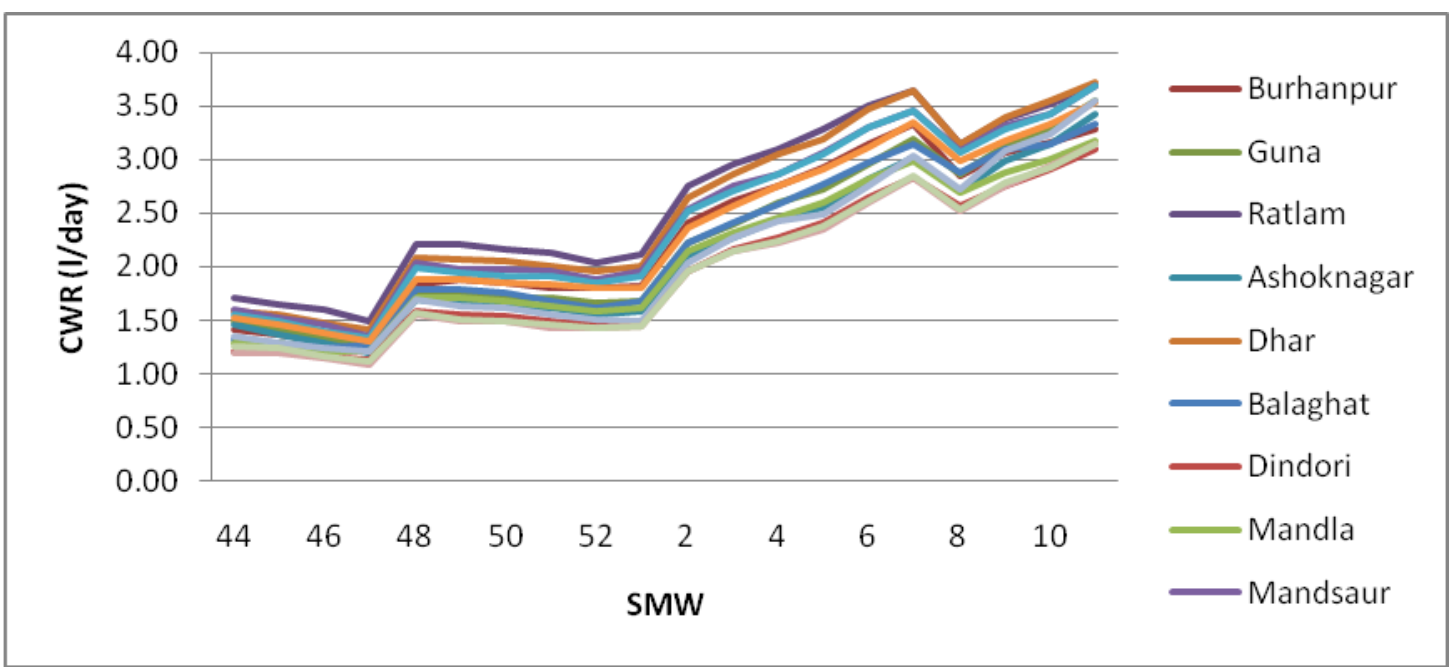


Fig.2 Stage wise variation in CWR of tomato in summer season at various districts of Madhya Pradesh

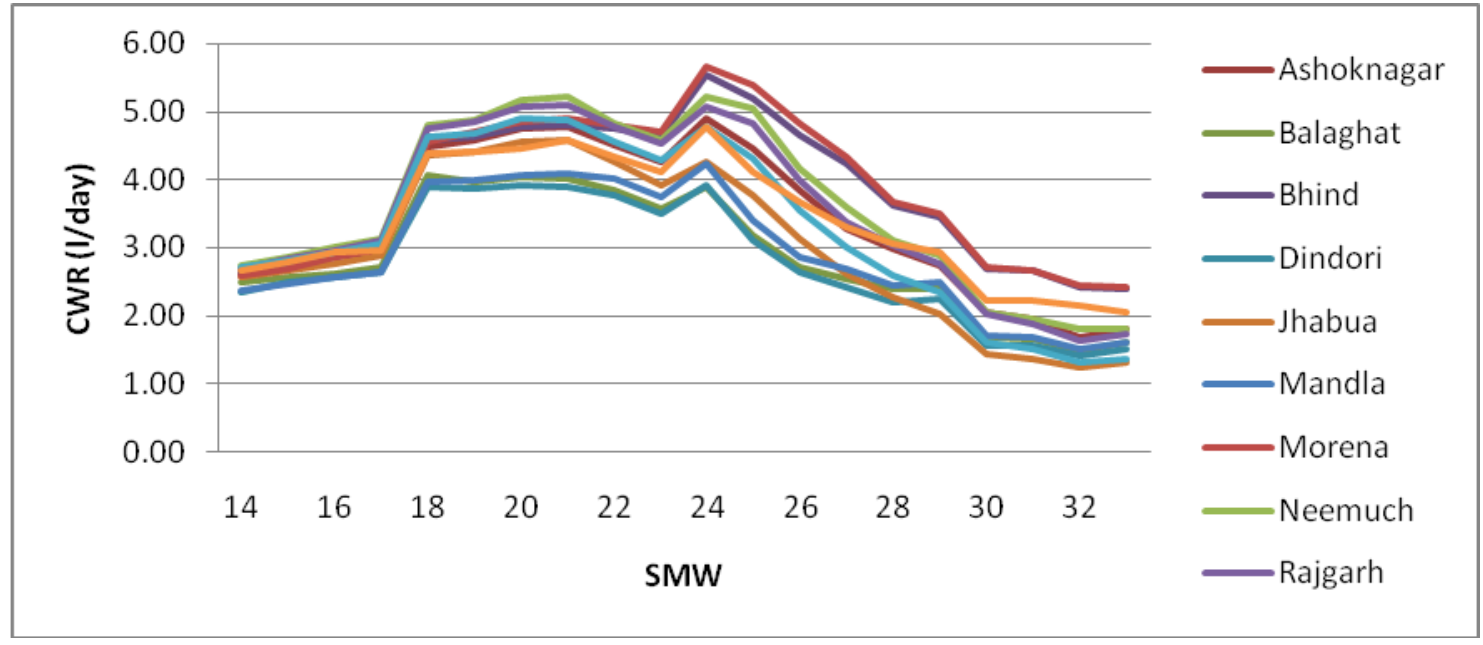

Fig.3 Stage wise variation in CWR of potato in winter season at various districts of Madhya Pradesh

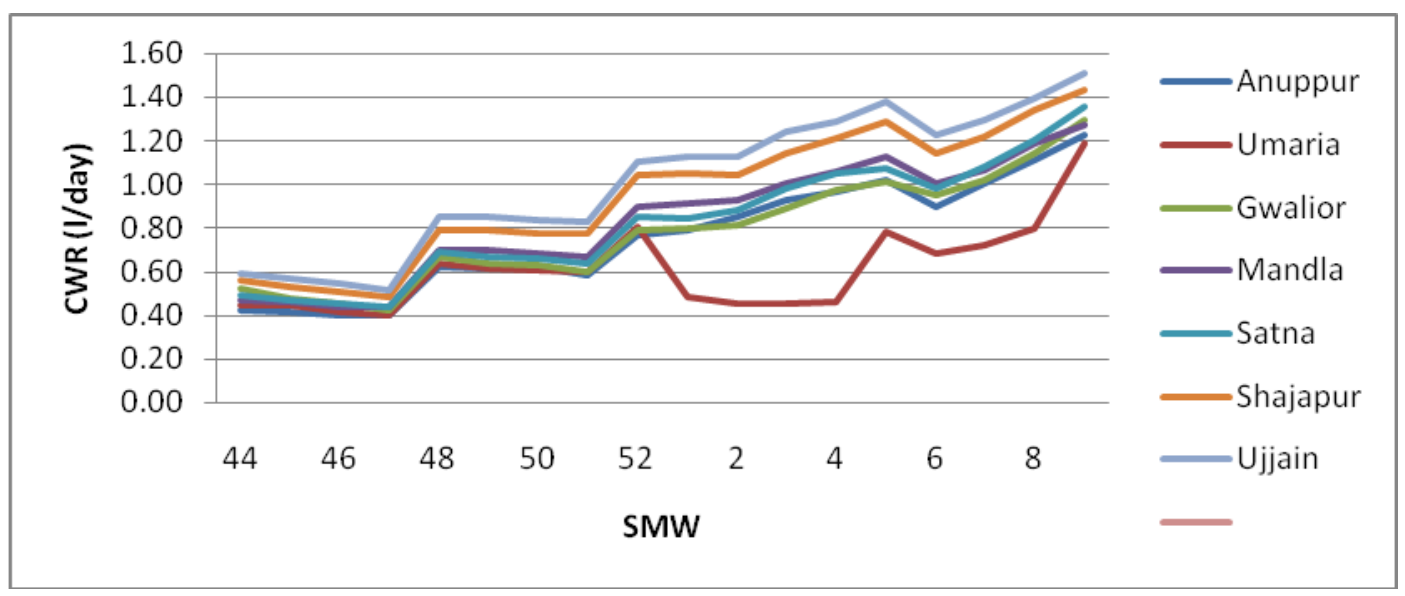

Fig.4 Stage wise variation in CWR of potato in summer season at various districts of Madhya Pradesh

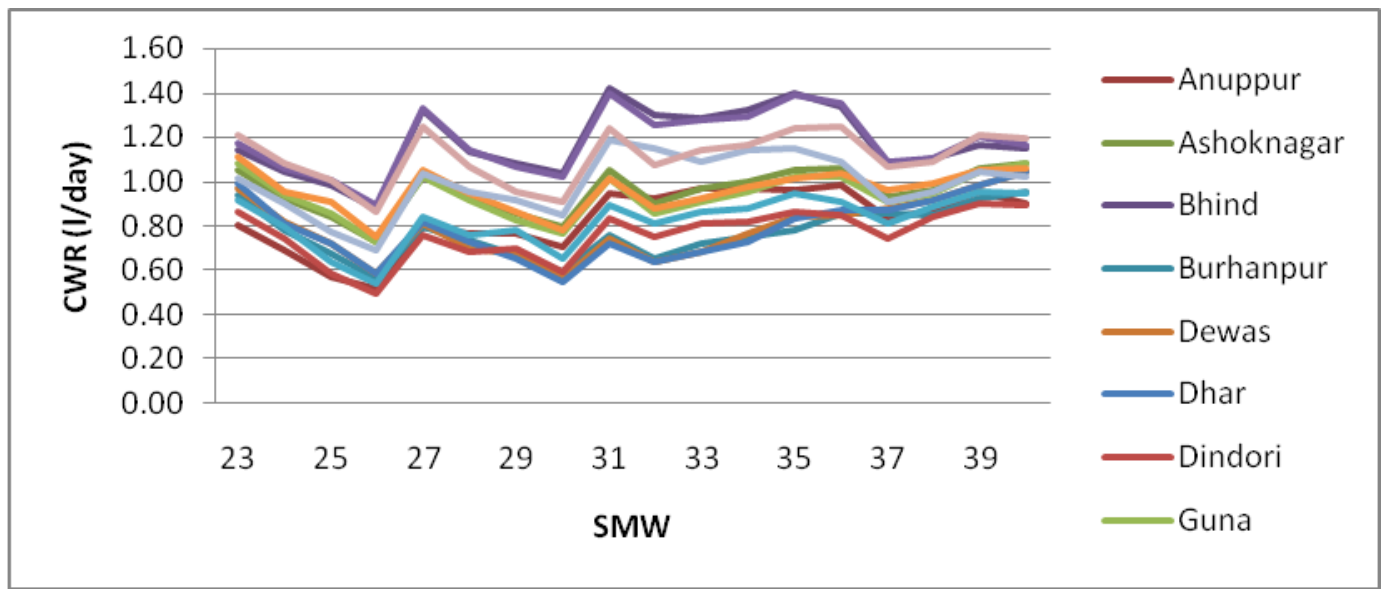


Fig.5 Stage wise variation in CWR of okra at various districts of Madhya Pradesh

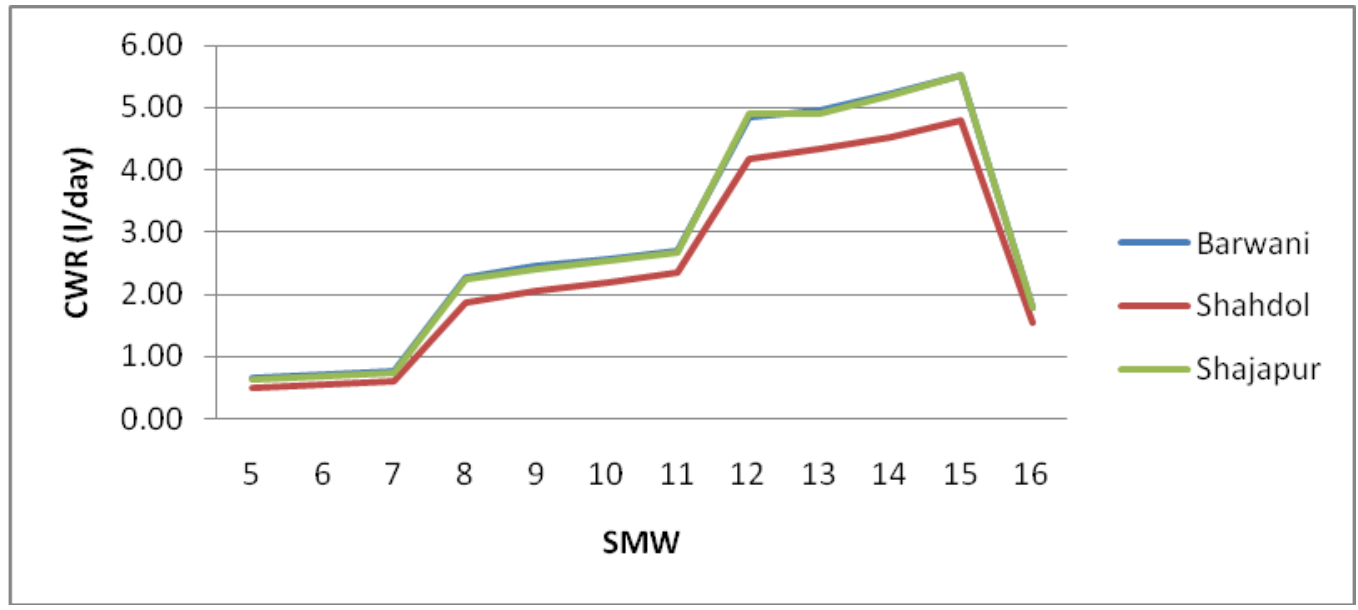

Fig.6 Stage wise variation in CWR of pea at various districts of Madhya Pradesh

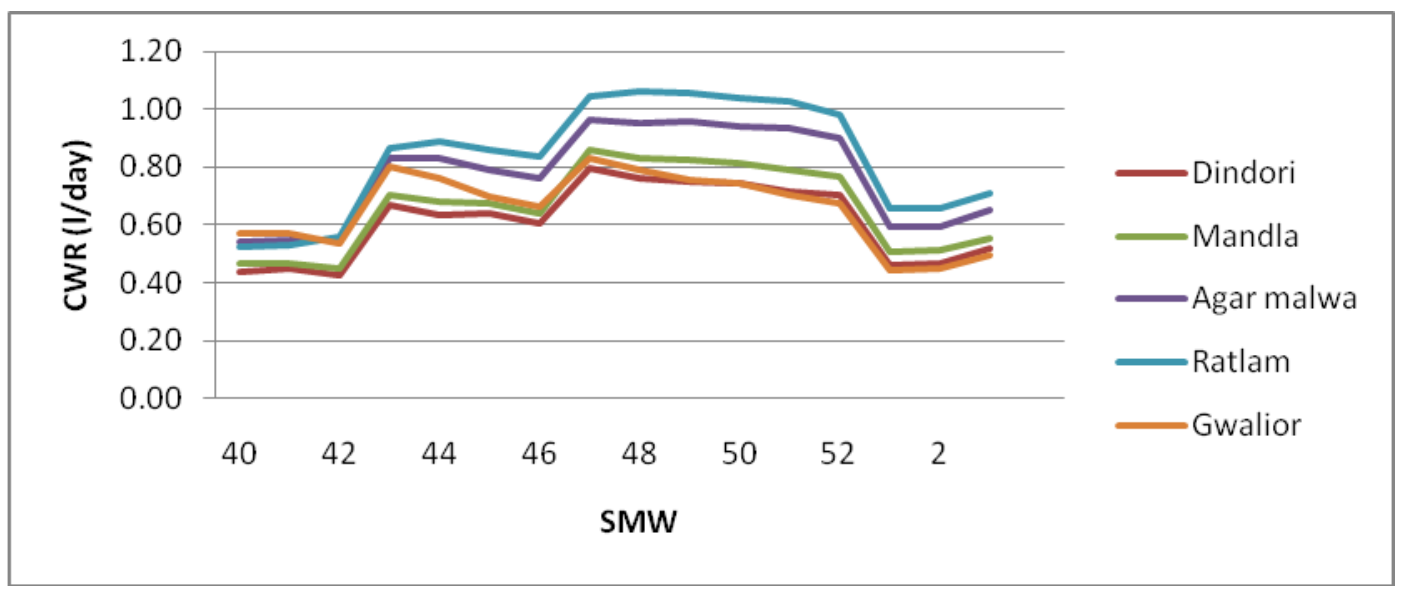

Fig.7 Stage wise variation in CWR of onion in winter season at various districts of Madhya Pradesh

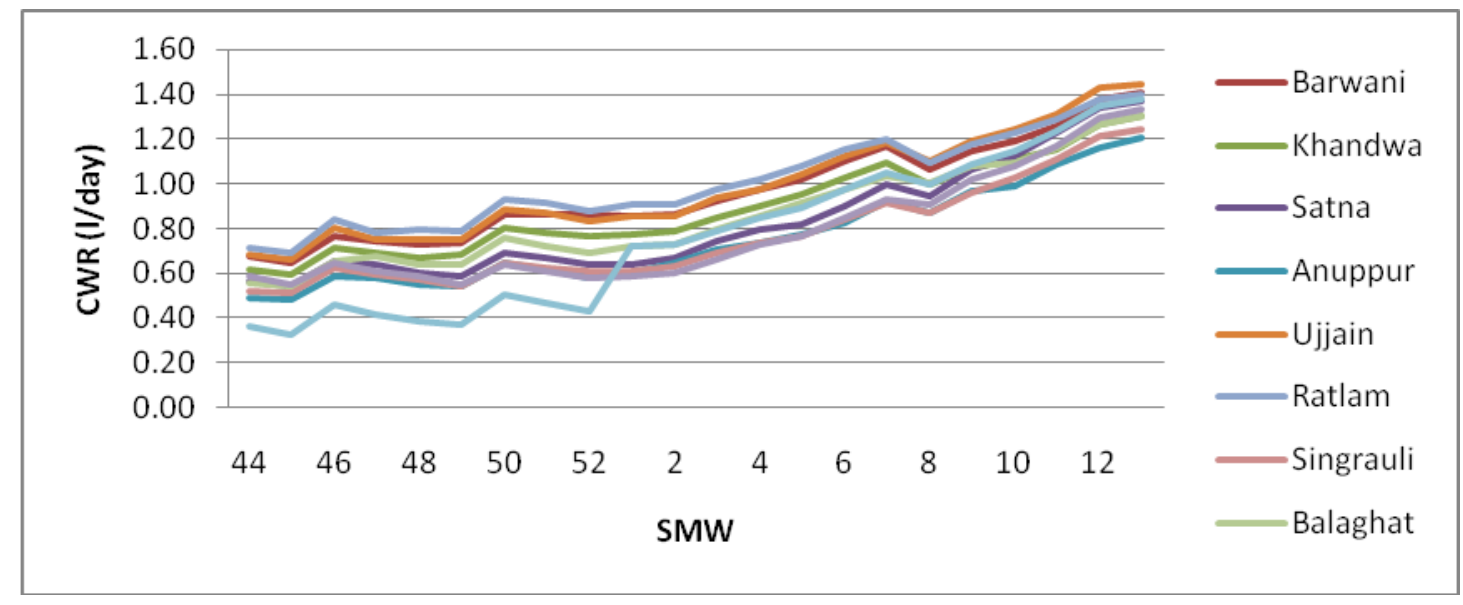


Fig.8 Stage wise variation in CWR of onion in summer season at various districts of Madhya Pradesh

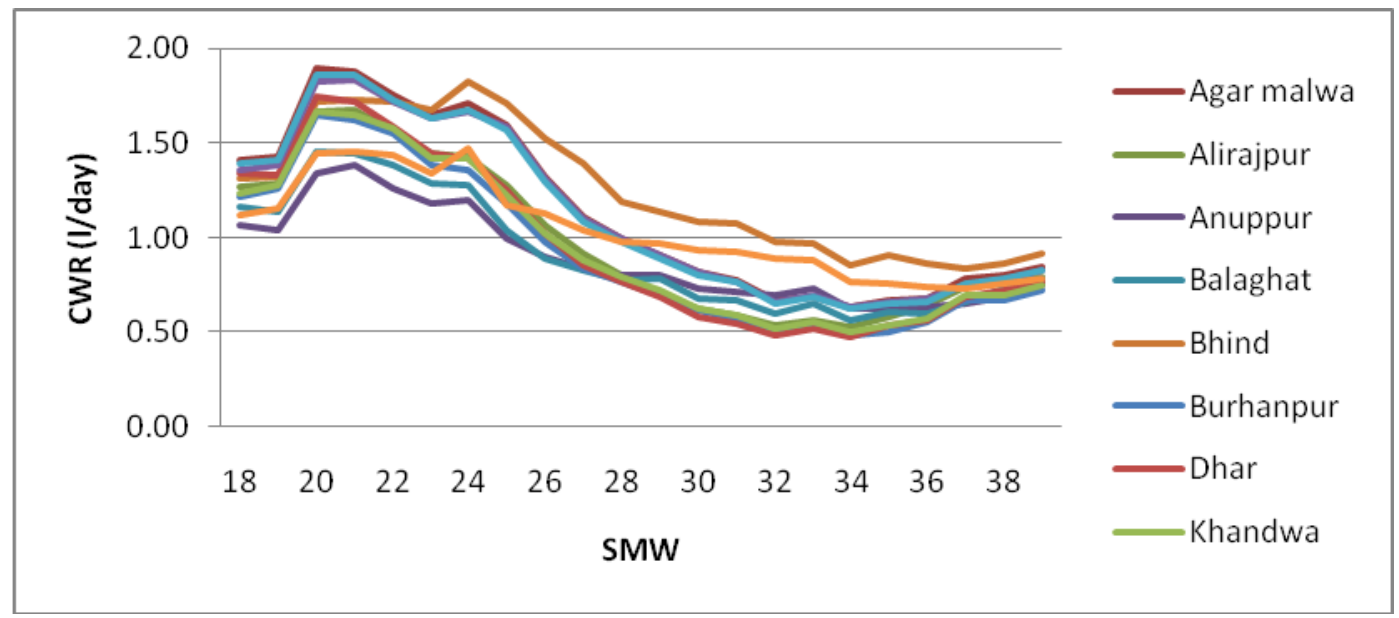

Fig.9 Stage wise variation in CWR of brinjal in winter season at various districts of Madhya Pradesh

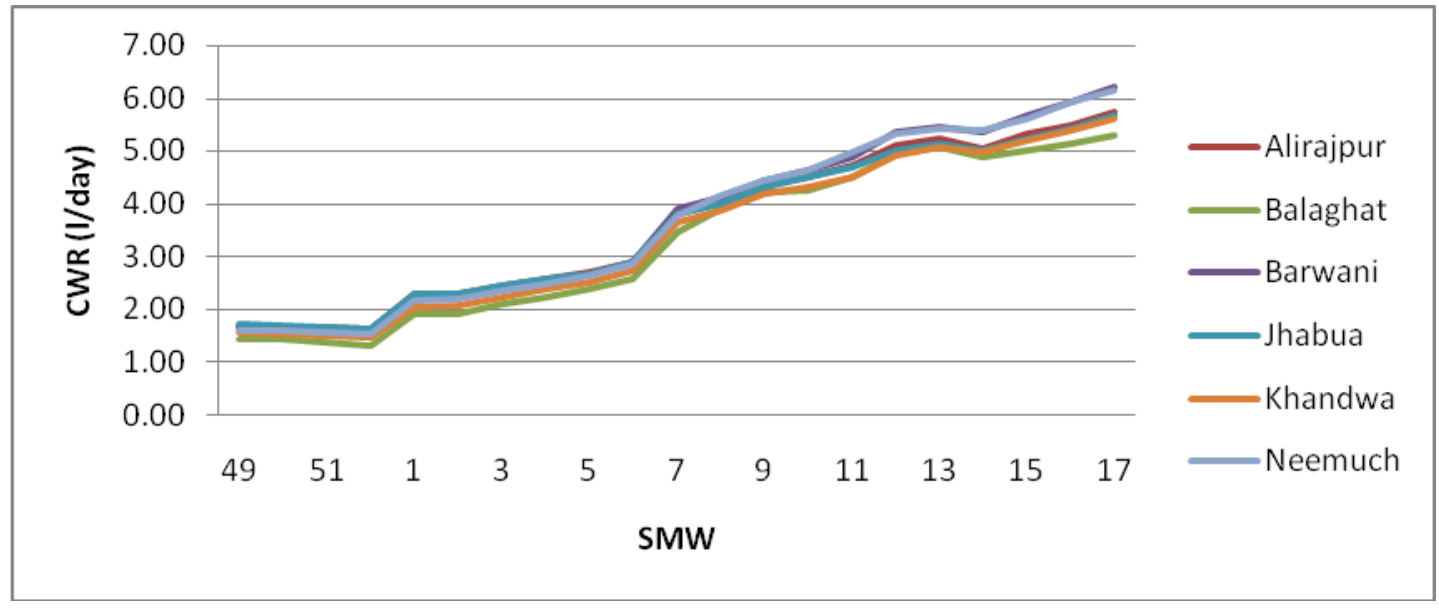

Fig.10 Stage wise variation in CWR of brinjal in mansoon season at various districts of Madhya Pradesh

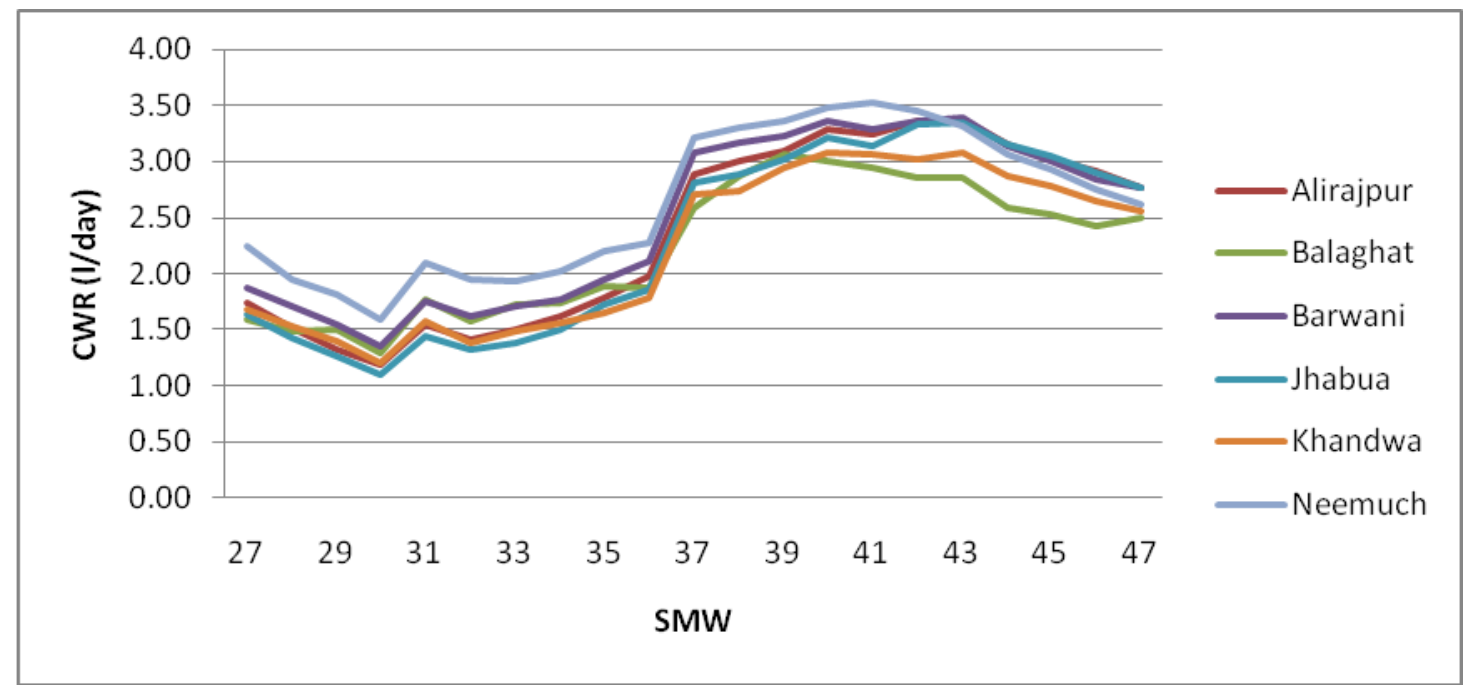


The CWR of pea in winter season is maximum in Ratlam (6.22 litre) during peak period and minimum in Dindori (1.31 litre) during lean period. The CWR of okra in summer season maximum in Mandsaur (20.59 litre) during peak period and minimum in Anuppur (1.48 litre) during lean period.

From the analysis of the result it was found that CWR of vegetable crops shows temporal and spatial variation because of the varying evapotranspiration.

It is revealed that summer season vegetable crops required maximum amount of water during mid stage and minimum during initial and late stage, winter and monsoon season crops required maximum water during mid stage and minimum during initial stage.

In short it can be concluded that a particular crop grown in different districts will require different amount of water due to varying evapotranspiration of these districts and that crop also shows variation in CWR in different growth stages because of variation in crop coefficient.

The CWR was found highest for Brinjal followed by tomato and lowest for pea followed by Potato. It means brinjal is most susceptible to water shortage whereas pea is least. From the analysis it was observed that in a particular district selection of crop should be made on the basis of its CWR and the $\mathrm{ET}_{0}$ of the district.

\section{References}

Allen et al., (1998). A report published on crop coefficient of vegetable crops. Food and Agricultural Organization of United Nations.

Allen, R.G., Pereira, L.A., Raes, D. and Smith M. (1998). Crop Evapotranspiration. Guidelines for computing crop water requirement. FAO Irrigation and Drainage Paper No. 56. FAO, Rome, Italy. pp. 300.

Chatterjee SK, Banerjee S. and Bose M. 2012. Climate change impact on crop water requirement in Ganga river basin, West Bengal, India. International Proceedings of Chemical, Biological and Environmental Engineering 46 (4).

Hajare HV, Raman NS and Dharkar J. 2008. New technique for evaluation of crop water requirement. Wseas Transactions on Environment and Development 4 (5).

Jensen, M.E., Burman, R.D. and Allen, R.G. 1990. Evapotranspiration and Irrigation Water Requirements. ASCE Manuals and Reports on Engineering Practice No. 70. American Society of Civil Engineers, New York.

Kumari M, Patel NR and Khayruloevich PY. 2013. Estimation of crop water requirement in rice-wheat system from multi-temporal AWIFS satellite data. International Journal of Geomatics and Geosciences 4 (1).

Michael AM. 1998. Irrigation Theory and Practice, third edition. Vikas Publishing House. PVT Limited, New Delhi.

Mohan, S. and Arumugam, N. 1996. Relative importance of meteorological variables in evapotranspiration: Factor analysis approach. Water Resources Management, 10 (1): 1-20.

NBSS \& LUP. National Bureau of Soil Survey and Land Use Planning. 2010.

Raju CR, Reddy YK, Satyanarayana TV and Yogitha P. 2016. Estimation of crop water requirement using Cropwat software in Appapuram channel command under Krishna western delta. International Journal of Agriculture Sciences 8 (31): 1644-1649.

Rao AS and Poonia S. 2011. Sensitivity of crop water requirements to elevated 
temperatures in arid Rajasthan. Annals of Arid Zone 50(2): 131-138.

Sachan S, Chandolal VK and Lohani AK. 2016. Probability analysis of rainfall and crop water requirement using CROPWAT model for crop planning in a canal command of upper Bhima Basin of Maharashtra. International
Journal of Agriculture, Environment and Biotechnology 9 (1): 123-135.

Yadav D, Awasthi MK and Nema RK. 2017. Estimation of Crop Water Requirement of Micro Irrigated Orchard Crops for different Agro-Climatic Conditions of Madhya Pradesh. International Archive of Applied Sciences and Technology 8(3): 18-24.

\section{How to cite this article:}

Upma Gautam, A. K. Nema and Jaiswal, R. K. 2019. Estimation of Crop Water Requirement (CWR) of Major Vegetable Crops of Selected Agro-climatic Zones of Madhya Pradesh, India. Int.J.Curr.Microbiol.App.Sci. 8(10): 895-904. doi: https://doi.org/10.20546/ijcmas.2019.810.104 